\title{
The 2014 Maastricht-NUS-MIT International Real Estate Finance \& Economics Symposium: Editors' Introduction to the Special Issue
}

\author{
Piet Eichholtz $^{1} \cdot$ David Geltner $^{2} \cdot$ Seow Eng Ong ${ }^{3}$ \\ Published online: 11 March 2016 \\ (C) The Author(s) 2016. This article is published with open access at Springerlink.com
}

\begin{abstract}
This is the Editors' Introduction to the special issue of the Journal of Real Estate Finance and Economics. The issue includes nine papers presented at the 2014 Maastricht-NUS-MIT (MNM) Symposium on International Real Estate Finance and Economics, held at Maastricht University in September 2014. This Introduction briefly describes the articles included in the special issue. The papers cover a broad range of topics.
\end{abstract}

Keywords REITs $\cdot$ Real estate rents $\cdot$ Private real estate funds

A total of thirteen papers were presented at the 2014 Maastricht-NUS-MIT conference, and nine of these have been selected for publication in the annual special conference issue of the Journal of Real Estate Finance and Economics. The papers range quite widely in their choice of topics, from REITs to individual property cash flows and from property level risk analysis to the performance of private real estate funds.

The conference welcomed two teams working on private real estate funds, which, despite their ubiquity in the institutional investment market, have not received much

Piet Eichholtz

p.eichholtz@maastrichtuniversity.nl

David Geltner

dgeltner@mit.edu

Seow Eng Ong

seong@nus.edu.sg

1 Finance Department, Maastricht University, Maastricht, The Netherlands

2 Center for Real Estate, Massachusetts Institute of Technology, Cambridge, MA, USA

3 Department of Real Estate, National University of Singapore, Kent Ridge, Singapore 
attention in the academic literature. Lynn Fisher and David Hartzell wrote a paper entitled "Class Differences in Real Estate Private Equity Fund Performance." Private funds tend to be classified into one of three classes on the basis of their investment strategy and implied risk: core, value-added, or opportunistic. However, the empirical evidence as to the discriminating power of this classification is almost non-existent. Fisher and Hartzell focus on the latter two classes and find quite strong differences in investment strategy, and also show that the performance of opportunistic funds tends to be somewhat lower than that of value-added funds, despite their higher risk. But these performance differences are not significant, which casts some doubt on the usefulness of the classifications currently used in the market.

The other paper concerning private real estate funds is by David Downs, Steffen Sebastian, Christian Weistroffer and René-Ojas Woltering and is entitled "Real Estate Fund Flows and the Flow-Performance Relationship". Using data from the German open-ended real estate fund industry, which mostly caters to retail investors, the paper's key question is whether capital flows into private real estate funds predict subsequent returns. The answer is that they do not, but that these flows chase past returns instead, albeit more strongly when these returns were very good than when they were bad. This convex relationship between past returns and fund flows is in line with the private equity literature. The authors do not find evidence that fund flows affect the prices of the real estate funds they study.

The only paper dealing with real estate sustainability, both in the conference and in this special issue, is by Shaun Bond and Avis Devine. This paper, entitled "Incentivizing Green Single-Family Construction: Identifying Effective Government Policies and Their Features," investigates whether current government incentives towards green housing development are effective. By studying cross sectional differences in these incentive programs across US municipalities, the authors are able to determine what works and what does not. They study at which level the government ideally should get involved and what type of incentive works best. The ideal level of the government's involvement depends on the program, with municipalities being most successful at construction-related schemes, and states better at incentives targeted at businesses. Counties do not seem to be very effective in this matter at all, lacking both the detailed local knowledge of municipalities and the financial clout of the states. Interestingly, the authors also find that green incentive schemes have an optimal age, and are most effective between 2 and 3 years after they are implemented.

The first of the two REIT-related papers presented at the conference is entitled "Related Party Transactions and Firm Value: Evidence from Property Markets in Hong Kong, Malaysia and Singapore", and is written by David Downs, Joseph Ooi, Woei-Chyuan Wong and S.E. Ong. The paper investigates exactly what the title suggests. The existing evidence on the effect of related party transactions is mixed, and since Asian REITs engage in such transactions on a rather large scale $(5.5 \%$ of total assets), they are an ideal testing ground to look at their effects on corporate value. The paper finds a positive association between related party transactions - especially acquisitions - and value. This is in line with the efficient contracting hypothesis.

The other REIT paper deals with REIT bonds. The paper, entitled "The Role of Debt Covenants in the Investment Grade Bond Market - The REIT Experiment", is written by Yongheng Deng, Erik Devos, Shofiquer Rahman and Desmond Tsang. The paper uses the fact that REIT bonds have covenant protection packages including limits to 
leverage and minimum interest coverage ratios to analyze the effect of these covenants on the cost of debt. First, however, the authors show that these covenants are indeed common among REITs, especially among the higher quality ones, and that they are only rarely binding. But they are indeed associated with a lower cost of debt. So from the viewpoint of the REITs, the covenants seem to imply very low marginal costs, yet material and instantaneous benefits.

Tingyu Zhou and John Clapp's paper "Predicting Risks of Anchor Store Openings and Closings" deals with a key risk source for retailers and retail real estate investors. If an anchor tenant walks away, competition in a center may be reduced, but it may also jeopardize traffic towards the center. A better understanding of this phenomenon and its opposite, the opening of an anchor store, is therefore very useful. The authors estimate a range of models whose outcomes can be used to calculate the odds of the opening and closing of anchor stores in the vicinity. They estimate a probit model to analyze anchor openings and closing over time, and a conditional logit model to estimate odds that an anchor tenants chooses a given location rather than another one. These models form the basis of a new tool that can be used to evaluate the risks associated with the opening of new anchor stores and the closing of existing ones, and the authors end their paper with a very illustrative case study of this new tool in action.

"The Rent Term Premium for Cancellable Leases" is a paper by Miki Seko, Kazuto Sumita and Jiro Yoshida. Many real estate lease contracts contain a clause that gives the tenant the option to walk away from the lease at no cost, and the authors aim to model the tenant's optimal cancellation decision, as well as the resulting rational lease pricing by the landlord. The rent term structure emerging from this model depends critically on the question whether the landlord faces leasing costs or not. If she does, for example because the property is located in a market with high vacancy, the term structure will be U-shaped, since the landlord dislikes short-term lease in that case. If, however, leasing costs are zero, which is likely to be the case in a market with low vacancy, then the term structure is upward sloping. The authors test their models on residential leases in Japan, and get results that are in line with the model's predictions.

The second paper that studies rents is by Xudong An, Jeffrey Fisher and David Geltner. It is entitled "Cash Flow Performance of Fannie Mae Multifamily Real Estate: Evidence from Repeated NOI and EGI Indices." The authors use repeated measures regression to estimate income in multifamily real estate. This provides a more accurate picture of multifamily income than traditional cash flow measures, which, according to the paper, tend to overestimate income growth in multifamily real estate. The resulting income indices show that Fannie Mae multifamily properties outperform those in the NCREIF database, especially during crisis periods. Within the Fannie Mae sample, low-income housing tends to underperform blue collar housing after implementing quality control variables in the model.

The last paper in this special issue studies Jensen's free cash flow hypothesis. In their paper "A Direct Test of the Free Cash Flow Hypothesis: Evidence from Real Estate Transactions," Yongqiang Chu and Peter Liu investigate whether corporate real estate buyers with ample cash flow or cash reserves pay more for their real estate than others. It turns out that they do. The effect seems substantial at first sight: A one standard deviation increase in free cash flow would increase the average property purchase price 
by approximately $20 \%$, depending on the model specification. However, comparing the cross sectional average and standard deviation of the free cash flow, this implies that the cash flow for the average firm in the sample should approximately triple for this effect to happen. The authors also find that the effect is stronger for low Tobin's Q firms, and that equity compensation is the only corporate governance instrument that helps reduce it.

Open Access This article is distributed under the terms of the Creative Commons Attribution 4.0 International License (http://creativecommons.org/licenses/by/4.0/), which permits unrestricted use, distribution, and reproduction in any medium, provided you give appropriate credit to the original author(s) and the source, provide a link to the Creative Commons license, and indicate if changes were made. 